\title{
Cannabinoids: Chemical Structure, Mechanisms of Action, Toxicity and Implications in Everyday Life
}

\author{
MARY NICOLETA LUPU'*, MAGDALENA MIULESCU², MADALINA NINA SANDU³, IULIA FILIP³, LAURA REBEGEA4, \\ OCTAVIAN CIOBOTARU ${ }^{1}$, GABRIELA STOLERIU ${ }^{5 *}$, KAMEL EARAR ${ }^{6}$, CARINA DOINA VOINESCU ${ }^{4}$, OANA ROXANA \\ CIOBOTARU ${ }^{4}$ \\ 'Dunarea de Jos University of Galati, Faculty of Medicine and Pharmacy, Surgical Department, 35 Al. I. Cuza Str., 800010, \\ Galati, Romania \\ 2Dunarea de J os University of Galati, Faculty of Medicine and Pharmacy, Department of Morphological and Functional \\ Sciences, 35 Al. I. Cuza Str., 800010, Galati, Romania \\ ${ }^{3}$ Hospital County Galati, 177 Brailei Str., 800578, Galati, Romania \\ ${ }^{4}$ Dunarea de Jos University of Galati, Faculty of Medicine and Pharmacy, Clinical Department, 35 Al. I. Cuza Str., 800010, \\ Galati, Romania \\ ${ }^{5}$ Dunarea de Jos University of Galati, Faculty of Medicine and Pharmacy, Research Center in the Field of Medical and \\ Pharmaceutical Sciences, Pharmacology Sciences Department, 35 Al. I. Cuza Str., 800010, Galati, Romania \\ ${ }^{6}$ Dunarea de J os University of Galati, Faculty of Medicine and Pharmacy, Department of Dental Medicine, 35 Al. I. Cuza Str., \\ 800010, Galati, Romania
}

\begin{abstract}
In the human body there is an endocannabinoid system consisting of cannabinoid receptors and endogenous transmitters - the endocannabinoids (anandamides). This cannabinoid system works by certain principles: the presynaptic neuron releases the neurotransmitter that reaches the postsynaptic neuron, activating it; at this level endocannabinoids are synthesized, whichhave retrograde transmission through the synaptic gap, reaching the cannabinoid receptors where they can inhibit the anterograde release of neurotransmitters. At the same level, certain exogenous substances, derived from plants and called phytocannabinoids may also work, the most known one being tetrahydrocannabinol. 9-D-Tetrahydrocannabinol is a component extracted from hemp plant with intense psychotic action but also with some medical applications. The result of the cannabinoid system activity is to obtain certain psychoactive effects, euphoria, relaxation, intense sensory experiences, pain relief but also changes in perception, attention deficit, etc. Synthetic cannabinoids are obtained to mimic the effects of marijuana, are major cannabinoid receptor agonists and are at increased risk of toxicity. Chronic consumption of such substances can cause memory disorders, pulmonary disorders and, most importantly, addiction.
\end{abstract}

Keywords: cannabinoids, marihuana, anandamide, tetrahydrocannabinol, endocannabinoids, cyclooxigenase, ethnobotanics, COX2, adverse drug reactions

In the human body there is an endocannabinoid system with a homeostatic role for energy consumption and temperature maintenance [1] composed of cannabinoid receptors $C B 1$ and $C B 2$, modulated by anandamide endocannabinoids and THC-type phytocannabinoids. Endocannabinoids are hydrophobic, lipid-like, thus lipophilic substances. They have retrograde transmission, moving from the postsynaptic neuron to the presynaptic one and modulating neuronal transmission. They are synthesized upon request, are not stored in vesicles with a short halflife and are degraded by FAAH hydrolase [2]. They play an important role in the functioning of memory, mood, reward system, glucose metabolism, lipolysis, energy balance, drug addiction [3].

The result of their attachment to cannabinoid receptors are the psychoactive effects of euphoria, relaxation, intense sensory experiences, changes in perception, attention deficit, pain relief $[4,5]$ accompanied by cardiovascular changes such as 20 to $100 \%$ pulse increase, hypotension, angina.

Short history:

- in 1964 the tetrahydrocannabinol, THC, the main marihuana component (Mechoulam and colleagues) was identified

- 1991 - Cannabinoid receptors CB1 (Gerrarad and colleagues) were identified and CB2 was discovered in 1993
- 1992-Anandamide, natural cannabinoid was identified.

The effects of exogenous cannabinoids on the human body

Marijuana is a drug known and used for hundreds of years for its medical and relaxing properties. Itcomes from the herb, Cannabis sativa and Cannabis indica, being the most used drug in the United States of America. It appears that its use was widely taken up after the Mexican soldiers smoked cannabis for its psychoactive effects in 1930. The leaves stem and flowers are consumed [6].

More than 400 substances - active compounds have been extracted from the plant. Approximately $60 \%$ of these are characteristic and are called cannabinoids. Molecular formulas: $\mathrm{C}_{21} \mathrm{H}_{30} \mathrm{O}_{2}$ (fig. 1). Molecular weight: $314.4 \mathrm{~g} / \mathrm{mol}$.

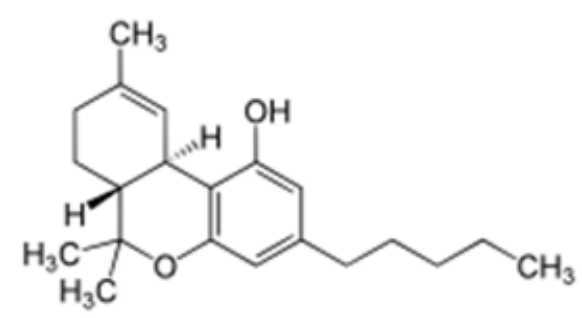

Fig. 1. Chemical formula for delta-9-tetrahydrocanabinol, $\Delta-9-\mathrm{THC}[7]$

\footnotetext{
* email: lupumarynicoleta@yahoo.com, stoleriugabriela@yahoo.com
} 
The psychoactive component is delta-9tetrahydrocanabinol, $\Delta-9-T H C$.

This is responsible for the states of euphoria, relaxation, special sensory experiences and, very important, the decrease in pain intensity. This is why marijuana is used in medicine to treat chronic pain [8], nausea and vomiting caused by chemotherapy treatments, and to improve spasticity from multiple sclerosis.

\section{Exogenous cannabinoids - absorption}

Marijuana is mainly consumed through smoking [9], by inhalation in the form of vapors and with fewer side effects than smoking [10], eaten in the form of cakes, lollipops but with varying absorption depending on the gastric content. It is also absorbed through skin applications in the form of cream, spray, oil, or even drops applied to the tongue [11-13].

-in case of consumption of tetrahydrocannabinol (THC) (marijuana), it enters the bloodstream, reaches the brain and replaces natural cannabinoids, overloading the brain

-by smoking, absorption occurs quickly, with the onset of action in min

$-\Delta-9-$ THC has an absorption of $10-35 \%$ and peak plasma concentration in about 8 minutes

-by ingestion, the onset of action is delayed 1 to $3 \mathrm{~h}$ and more difficult to evaluate; absorption depends on gastric content and metabolism, varying between 5 and $20 \%$. The plasmatic peak is between 2 and $6 \mathrm{~h}$ after ingestion

-the half-life is from 2 to $57 \mathrm{~h}$. In about 5 days, more than $90 \%$ of $\Delta$-9-tetrahydrocanabinol (THC) is excreted from the body [14].

-in order to detect marijuana consumption, it is recommended to measure the THC sanguine level.

Among the more important side effects are bronchoconstriction effects [15], pulmonary damage in a more severe time than smokers, impairment of consciousness and even mental impairment in juvenile dependent on marijuana consumption [16]. The signs of acute marijuana intoxication are red eyes, increased appetite, dry mouth and increased pulse [17]. There are currently studies showing the link between marijuana consumption and the occurrence of psychotic disorders [18].

\section{The role and functions of endocannabinoids in the human body}

Cannabinoid receptors CB1 from endocannabinoid system are found in the frontal cortex, hippocampus, basal ganglia, cerebellum, striatum nucleus, connective tissue, gonads, endocrine glands. They are responsible for psychotropic effects [19] and mediate inhibition of neurotransmitter release.

Cannabinoid receptors CB2 are found peripherally in lymphoid organs and immune cells (splenic macrophages, $T$ and $B$ type lymphocytes), kidneys, bones, peripheral nerves, some vessels.

Natural cannabinoids are the anandamide and 2arachidonoyl glycerol (2 AG) $[20,21]$ which act on cannabinoid receptors. The name of the anandamide comes from the Sanskrit language, ananda meaning happiness.

The cannabinoid system in the body functions according to certain principles: the presynaptic neuron releases the neurotransmitter that reaches the postsynaptic neuron, activating it. Endogenous cannabinoids, chemical messengers of the endocannabinoid system, are synthesized on demand from lipid precursors in the neuron; once released, they return to the presynaptic neuron, where they are attached to cannabinoid receptors [22]. In this way cannabinoids can control the activated presynaptic cells, inactivating them and limiting the amount of neurotransmitters released, influencing the message at all levels: transmission, processing and receiving.

The endocannabinoid system is closely related to certain lipid mediators of the prostaglandin or leukotriene type. Cyclooxigenase type 2 (COX2) acts on the arachidonic acid, resulting in prostaglandins and eicosanoids. [23] The effect of cyclooxygenase on endocannabinoids (amandamide and 2-arachidonyl glycerol) may result in prostamides and prostaglandins $[24,25]$. Hence, it could be concluded that COX 2 inhibition could affect the activity of the central nervous system and immune cells [26].

\section{Cannabinoids - toxicity and implications in everyday life}

Synthetic cannabinoids are obtained to mimic the effects of marijuana. They are major agonists on the CB1 and CB2 cannabinoid receptors and have a high toxicity risk with manifestations of lethargy, agitation, tachycardia, hyperthermia, renal failure, myocardial infarction, seizures, death. Consumption of synthetic cannabinoids was first recorded in 2009, and in 2011 there was the highest consumption among 18 to 20-year-olds (60.8 emergency department presentations per 100,000 inhabitants) [27].

These synthetic cannabinoids are sold under different names: spice, K2, Black Mambo, Aroma, Dream, Bonzai, ethnobotanics in our country [28].

They are in fact a mixture of dried and crushed herbs along with various additives produced in clandestine laboratories, withoutknowing exactly the composition and origin of the ingredients. The European Monitoring Center for Drugs and Drug Addiction analyzed the composition of these substances and found that they can contain cannabinoids, tocopherol - vitamin E [28].

Commercialized under different names - aromatic sticks, plant fertilizer, bath salts, jewelry cleaning solutions, etc. they are easily obtainable, affordable, producing marijuana-like effects after consumption, but more intense. They have high toxic potential [29] and may be up to 100 times more potent than tetrahydrocannabinol, they cannot be detected in urine like usual drugs, and require highly performant laboratories to detect consumption [30].

Consumption of ethnobotanics causes euphoria, lack of fatigue, decreased appetite, relaxation, amnesia, detachment, strong sensory experiences, changes in perception, pain relief, if it exists [6]. In addition to such sensations, hallucinations, panic attacks, paranoia, aggressive behavior, dizziness, somnolence, agitation, headache, vertigo, sudden mood swings, attention deficit and memory, speech [28], red eyes, sweating, nausea, vomiting, respiratory complications, cardiovascular, renal, seizures, loss of knowledge, coma, even death may occur in case of an overdose.

This consumption occurs on the background of family or school problems. It can be associated with alcohol consumption and smoking [31].

From a cardiovascular point of view, patients may experience an increase in heart rate by $20-100 \%$, hypertension or hypotension, peripheral vasodilation with orthostatic hypotension, increased myocardial oxygen consumption with angina symptoms, acute myocardial infarction, congestive heart failure, and even stroke in those with a history of cerebrovascular disease [32].

In terms of the respiratory system, bronchoconstriction, coughing, abdominal sputum, wheezing, respiratory 
depression requiring respiratory protections, aspiration pneumonia may occur.

Also, severe renal impairment with acute renal insufficiency due to renal ischaemia secondary to hypovolemia can be observed through directnephrotoxicity of synthetic cannabinoids or additional compounds, rhabdomyolysis and metabolic acidosis.

In such cases, patients require: consciousness monitoring, orotracheal intubation and mechanical ventilation for hypoventilation and prevention of aspiration pneumonia, cardiovascular and renal function control (creatinine, diuresis).

The treatmentalso includes, besides respiratory support, sedation for agitated, combative, aggressive patients, done through titration of benzodiazepines according to the patient's needs, hydro-electrolytic rebalancing by hydration, correction of electrolyte imbalances - especially potassium depletion, blood glucose control (150-180 mg/dL), forced diuresis to avoid acute tubular necrosis in the kidneys, controlling convulsions and hyperthermia. In severe cases, only monitoring and intensive care can help recover multiple organ dysfunctions.

\section{Conclusions}

In 2015 there were a large number of presentations in the emergency room due to ethnobotanical consumption, with a very serious general state, some of them requiring hospitalization and intensive care.

Because of the increase in psychoactive drug use, this paper presents the role and functions of the endocannabinoid system in the human body and how certain exogenous substances derived from plants and called phytocannabinoids, such as 9- $\Delta$-tetrahydro-cannabinol, can work. They have effects such as euphoria, relaxation, intense sensory experiences, pain relief, but also changes in perception, attention deficit, etc. It is known to have an increased risk of toxicity. Chronic consumption of such substances can cause memory disorders, pulmonary disorders and, most importantly, addiction.

\section{References}

1.LU, H.-C., MACKIE, K., Biol. Psychiatry., 79, no. 7, 2016, p. 516-525. 2.NASSER, Y., BASHASHATI, M., ANDREWS, C.N., Neurogastroenterol. Motil., 26, 2014, p. 447-454.

3.MECHOULAM, R., PARKER, L.A., Annu. Rev. Psychol., 64, 2013, p. 21-47.

4.MARTINEZ-PINILLA, E., VARANI, K., REYES-RESINA, I., ANGELATS, E., VINCENZI, F., FERREIRO-VERA, C., OYARZABAL, J., CANELA, E.I., LANCIEGO, J.L., NADAL, X., NAVARRO, G., BOREA, P.A., FRANCO, R., Front. Pharmacol., 8, 2017, p. 744.

5.RAMESH, D., D'AGATA, A., STARKWEATHER, A.R., YOUNG, E., Clin. J. Pain., 34, 2018, p. 8-14.

6.*** NIDA. Marijuana. National Institute on Drug Abuse website. https://www.drugabuse.gov/drugs-abuse/marijuana. Accessed February 9, 2019.

7.BORGES, R.S., BATISTA, J J R., VIANA, R.B., BAETAS, A.C., ORESTES, E., ANDRADE, M.A., HONORIO, K.H., ALBERICO, B. F., DA SILVA, A.B.F., Molecules, 18, 2013, p. 12663-12674.
8.SCHATMAN, M.E., Medical cannabinoids: an update on what you need to know for your practice. PAIN WeekEnd; Houston, Texas; November 14, 2015.

9.DOUGLAS, I.S., ALBERTSON, T.E., FOLAN, P., HANANIA, N.A., TASHKIN, D.P., UPSON, D.J ., LEONE, F.T., Ann. Am. Thorac. Soc., 12, no. 11,2015, p. 1700-171

10.MACCOUN, R.J., MELLO, M.M., N. Engl. J. Med., 372, no. 11, 2015, p. 989-991.

11.TOADER, E., BAHRIN, L.G., JONES, P.G., HOPF H., SARBU, L.G., STOLERIU, G., Rev. Chim. (Bucharest), 67, no. 8, 2016, p. 1520-1522. 12.DAVID, S., KNIELING, A., DAMIAN, S.I., DIAC, M., SANDU, I., IOV, T., Rev. Chim. (Bucharest), 69, no. 5, 2018, p. 1216.

13.DAVID, S.M., ILIESCU, D.B., SANDU, I., PARASCHIV, D.E., TEODORESCU, C., KNIELING, A., Rev. Chim. (Bucharest), 68, no. 5, 2017, p. 1031.

14.CONDRATOVICI, C.P., BACAREA, V., PIQUE, N., Gastroenterol. Res. Pract., 2, 2016, p. 1-7.

15.SAVAGE, S.R., ROMERO-SANDOVAL, A., SCHATMAN, M., WALLACE, M., FANCIULLO, G., MCCARBERG, B., WARE, M., J. Pain., 17, no. 6, 2016, p. 654-668.

16.SEMPLE, D.M., MCINTOSH, A.M., LAWRIE, S.M., J. Psychopharmacol., 19, 2005, p. 187-194.

17.FRANZ, C.A., FRISHMAN, W.H., Marijuana use and cardiovascular disease. Cardiol. Rev. 24, 2016, p. 158-162.

18.WEISER, M., NOY, S., Dialogues. Clin.Neurosci.,7, 2005, p. 81-85. 19.MLOST, J., KOSTRZEWA, M., MALEK, N., STAROWICZ, K., Int. J. Mol. Sci., 19, 2018, p. 342.

20.REISENBERG, M., SINGH, P.K., WILLIAMS, G., DOHERTY, P., Philos. Trans. R. Soc. Lond. B. Biol. Sci., 367, 2012, p. 3264-3275.

21.KATONA, I., FREUND, T.F., Annu. Rev. Neurosci., 35, 2012, p. 529558.

22.OHNO-SHOSAKU, T., KANO, M., Curr. Opin.Neurobiol., 29, 2014, p. 1-8.

23.TATU, A.L., NWABUDIKE, L.C., Am. J. Ther., 24, 2017, p. e477-e480. 24.OHNO-SHOSAKU, T., KANO, M., Curr. Opin.Neurobiol., 29, 2014, p. 1-8.

25.PAUNESCU, H., COMAN, O.A., COMAN, L., GHIPÃ, I., GEORGESCU, S.R., DRÃIA, F., FULGA, I., J Med Life.,4, 2011, p. 11-20.

26.FILIP-CIUBOTARU, F., MANCIUC, C., STOLERIU, G., FOIA, L., Rev. Med. Chir. Soc. Med. Nat. Iasi,120, no. 1,2016, p. 29-33.

27.***Highlights of the 2011 Drug Abuse Warning Network (DAWN). Findings on Drug-Related Emergency Department Visits. The DAWN Report. http://www.samhsa.gov/data/sites/default/files/DAW N127/ DAWN127/sr127-DAW N-highlights.htm. February 2013

28.*** Eurpean Monitoring Centre For Drugs and Drud Addiction. Synthetic cannabinoids and 'Spice' drug profile, emcdda.europa.eu/ topics/pods/synthetic-cannabinoids

29.HALL, W., Addiction, 110, no. 1, 2015, p. 19-35.

30.AUER, R., VITTINGHOFF, E., YAFFE, K., KUNZI, A., KERTESZ, S.G., LEVINE, D.A., ALBANESE, E., WHITMER, R.A., JACOBS, D.R. JR., SIDNEY, S., GLYMOUR, M.M., PLETCHER, M.J. . JAMA Intern. Med., 176, no. 3, 2016, p. 352-361.

31.MEIER, M.H., CASPI, A., AMBLER, A., HARRINGTON, H., HOUTS, R., KEEFE, R.S.E., MCDONALD, K., AIMEE WARD, A., POULTON, R., MOFFITT T.E., Proc. Natl. Acad. Sci. USA., 109, no. 40, 2012, p. E2657E2664.

32.RUMALLA, K., REDDY, A.Y., MITTAL, M.K., J. Neurol. Sci., 364, 2016, p. 191-196.

Manuscript received: 6.09 .2018 